\title{
ПУБЛИКА ЦИИ
}

\section{ЯЗЫКИ ТАТАР И КЫПЧАКОВ В РАМКАХ ОДНОЙ ЛИНГВОГЕОГРАФИЧЕСКОЙ РЕКОНСТРУКЦИИ}

\author{
А.В. Шумкин \\ Федеральное агентство научных организаиий \\ 119334, Москва, Российская Федерация \\ E-mail:arsen1293@rambler.ru
}

Цель: рассмотреть проблемы происхождения и развития нескольких тюркских языков, распространённых на Северном Кавказе.

Материалы исследования: эпоха владычества в степях Азии и Восточной Европы Тюркского каганата положила начало формированию древнетюркской литературной традиции, которая первоначально велась на оригинальной орхоно-енисейской письменности, а впоследствии в княжестве Кочо и государстве Караханидов была переведена на заимствованный у согдийцев алфавит. Караханид Махмуд ал-Кашгари в своём составленном на арабском языке сочинении впервые описал тюркские разговорные наречия, отличавшиеся от древней письменной нормы. Среди них основное его внимание привлекли языки кочевых конфедераций огузов и кыпчаков, которые друг за другом занимали степи Восточной Европы и Средней Азии. При помощи привлечения сведений ал-Кашгари в статье продемонстрировано, что на территории, занятой кыпчакской конфедерацией, не только сохранялись огузские наречия, использовавшиеся присоединёнными к кыпчакам огузскими племенами канглы и карабёркли, но и распространилась принесённая самими кыпчаками на запад кыргызская ветвь тюркских языков. Возникновение и завоевания Великой Монгольской империи навсегда изменили как языковые границы, так и литературные каноны Средней Азии, Сибири и Восточной Европы. При Монгольской империи на этой территории установилась практика двуязычия. Литературные каноны отныне и вплоть до первой трети XX века основывались на тюркской речи Чагатайского улуса Монгольской империи. Что же касается разговорной речи, то исследуя рукопись Антонио де Финале, составленную в начале XIV века на территории Улуса Джучи, и ряд документов XVI-XVIII веков, написанных на языке литовских татар, автор раскрывает историю становления в Дешт-и Кыпчаке татарской ветви тюркских языков.

Результаты и научная новизна: на основе этих сведений в статье удаётся сделать вывод, что как чагатайский, так и золотоордынский языки были принесены на запад в ходе монгольских завоеваний. Сквозь призму этих событий в статье рассматриваются проблемы происхождения и развития нескольких тюркских языков, распространенных на Северном Кавказе.

Ключевые слова: Северный Кавказ, тюркские языки, историческая лингвистика, татарский язык, кипчакский язык, огузский язык.

Для цитирования: Шумкин А.В. Языки татар и кыпчаков в рамках одной лингвогеографической реконструкции // Золотоордынское обозрение. 2016. Т. 4, № 4. 2016. C. 698-723. DOI: 10.22378/2313-6197.2016-4-4.698-723 
Со времён античности Северный Кавказ известен как один из самых полиэтничных регионов Восточной Европы. В средние века пёструю этнографическую карту этого горного ареала пополнили тюркоязычные кочевники, осевшие среди местных кавказских и ираноязычных народов. На данный момент хорошо изучены пути миграции в этот регион ногайцев, покинувших во второй половине XVI - первой трети XVII в. Заволжье [76, с. 273276, 299-301]. Что касается туркмен, то первая их группа переселилась сюда ещё в конце XVI в. из Ширвана [7, с. 109], а вторая около 1770 г. из закаспийских степей $[17$, с. 165]. Но к XVI столетию на Восточном и Центральном Кавказе уже проживало более раннее тюрко-язычное население, сосредоточившееся в двух группах сельских обществ. Восточно-кавказскую группу составляли шамхальство Тарковское и связанные с ним вассалитетом селения Брагуны, Эндирей, Костек, Аксай, Дженгутай. Центрально-кавказскую группу - Карачай, Малкар, Чегем, Холам, Безенги, Урусбий. Поскольку история этих сельских объединений отразилась в письменных источниках весьма эпизодично, среди исследователей проблемы их возникновения и этногенеза жителей до сих пор вызывают много вопросов.

Недостаток документальных данных заставляет искать альтернативные способы пролить свет на историю тюркских обществ Северного Кавказа. Самый надёжный путь к разрешению проблемы их генезиса в первой трети XIX в. открыло появление методов сравнительно-исторического языкознания. Ещё в 1823 г. С.М. Броневский предпринял первую попытку определить язык-основу, от которого отделились соответствующие языки Центрального Кавказа, и реконструировать промежуточный этап развития тюркской языковой семьи, завершившийся их образованием [13, с. 197]. Однако, уровень знаний, накопленных к тому времени ориенталистами в области тюркского языкознания, не позволял сделать достаточно надёжных выводов. В частности Броневский считал, что эти общества выделились из состава Ногайской Орды. Основной проблемой, с которой он столкнулся при попытке реконструкции прошлого тюрков Северного Кавказа, было отсутствие как общей классификации, так и средневековых памятников их языков. Ведь в Азии и Восточной Европе со времён монгольских завоеваний утвердились общие литературные нормы, основанные на письменных традициях тюркского языка чагатайского улуса монгольской империи [9, с. 606-607]. Таким образом, первоначально в распоряжении ориенталистов находились только полевые материалы по разговорным тюркским языкам, близким северокавказским, собранные членами различных научных экспедиций, предпринимавшихся начиная с XVIII века.

Выход из сложившейся ситуации нашёл в 1824 году Г.Ю. Клапрот, заказав в Библиотеке венецианского собора св. Марка копию подаренной ей в 1362 г. Ф. Петраркой рукописи Антонио де Финале [87, с. 116-117]. Вторая часть этого кодекса представляла собой самый ранний известный памятник тюркского языка, носящего те же основные генетические характеристики, что и северокавказские. Осуществлённая Клапротом спустя четыре года публикация первой части рукописи А. де Финале, выполненной на латинской графической основе, положила начало обширной исследовательской литературе [88, с. 122 254]. Ещё в XVII в. известный итальянский библиограф Я.Ф. Томмазини присвоил кодексу обозначение «Alfabetum Persicum, Comanicum et Latinum». Bce 
последующие издания априори приняли объяснение этого названия, предложенное Клапротом, сопоставившим первую часть рукописи со сведениями Г. де Рубрук. Клапрот сформулировал его следующим образом: земля кумановкыпчаков в Северном Причерноморье была перевалочным пунктом для европейцев, направлявшихся в Татарию, что и сделало куманский языкомпосредником в общении между Европой и Азией [88, с. 119-120].

Впоследствии А.С. Фиркович собрал коллекцию еврейских рукописей, среди которых был обнаружен ряд выполненных арамейской и квадратной письменностью тюркоязычных памятников XVI-XVIII вв. с теми же характерными особенностями. Наконец внимание исследователей привлекла третья группа генетически родственных документов XVI-XVII вв., принадлежавших армянским общинам Каменца-Подольского и Львова.

Первую попытку научно систематизировать языки тюрков Кавказа предпринял ещё И.А. Гильденштедт, который отличал наречие, распространённое среди жителей сельских обществ Восточного Кавказа, известных под политонимом кумуков, от терекменского и ногайского [19, с. 253]. Хотя материалами по языку горских обществ центральной части Кавказа он и не располагал, но предполагал сходство между ним и наречием близживущих ногайцев $[19$, с. 224]. Лишь в середине следующего века на специфическую близость языка горцев и кумуков обратил внимание персидский историк А. Бакиханов, который считал, что «жители Балкара и окрестных с ним Чегема, Баксана, Бизенги и других говорят на языке тюрки кумукского наречия, что доказывает сходство этих народов» [7, с. 14-15]. Среди учёных взгляд Бакиханова на эти языки как на две чрезвычайно близкие группы говоров вскоре получил признание $[44$, с. $4 ; 48$, с. 838,$843 ; 43$, с. $41-42 ; 34$, с. 41 ; 2, с. 23$]$. Однако благодаря научному авторитету Гильденштедта обе точки зрения продолжали некоторое время сосуществовать в этнографической литературе, а порой даже причудливым образом переплетались [17, с. $169 ; 35$, с. $162-163 ; 12$, с. 290 ; 13 , с. $197 ; 51$, с. $8 ; 26$, с. $20 ; 72$, с. 33,$93 ; 6$, с. $404-405 ; 5$, с. 149$]$.

Впрочем, в первой половине XIX в. учёные, пытавшиеся составить классификацию языков тюркских народов, руководствовались в большей мере географическим, чем сравнительно-историческим принципом [85, с. 1-25]. И только во второй половине того же столетия, после того, как И.Н. Березин разработал классификацию, базировавшуюся на чертах материального сходства тюркских языков, работа по их систематизации перешла на качественно более высокий уровень [85, с. 26-84]. Рассмотрев все доступные ему материалы западно-тюркских языков, Березин разделил их на три ветви. Ряд языков, генетически близких к северокавказским, он объединил в «татарскую» ветвь, одной из самых характерных особенностей которой было соответствие в ауслауте фонемы /w/ звуку /g/ остальных тюркских языков [85, с. 27, 4564]. Язык первой части рукописи А. де Финале, опубликованной Клапротом, Березин уверенно отнёс к другой, чагатайской ветви тюркских языков $[85$, c. 26, 39-43].

Собственные поправки в созданную Березиным классификацию внёс В.В. Радлов, попытавшийся включить в неё также восточно-тюркские языки [90, с. 280-291]. Тем временем рукопись А. де Финале была полностью опубликована в 1880 г. Г. Кууном под заглавием Codex Cumanicus [89, с. 1-233]. Ориентируясь в основном на специфические особенности её второй части, 
Радлов отнёс «куманский» язык к татарской ветви классификации Березина, которую предложил называть «кыпчакской» [91, с. 6]. Ему представлялось, что среди татар растворились остатки уйгур и куманов, которые оказали определённое влияние на становление их «кыпчакского» языка [59, с. XIIIXIV]. Не согласился с ним Ф.Е. Корш, который также как и Березин объединил язык Codex Cumanicus c чагатайским. Однако он считал их восточнотюркскими языками, вместо того чтобы отнести к одной ветви с их живыми среднеазиатскими родственниками [66, с. 80-81].

Только в первой четверти XX в. А.Н. Самойлович, выделив основные регулярные звуковые соответствия, выработал общую классификацию тюркской языковой семьи и посчитал возможным вычленить из состава её «татарской» ветви три отдельные группы [66, с. 53-54, 77-91]. Полное генетическое сходство объединяло наречия карачаевцев, малкарцев, и кумуков, по его мнению, лишь с языком татар и караимов. Область распространения этих близкородственных языков была очерчена границами Восточной Европы. Остальные две группы «татарских» языков охватили ареал обитания алтайцев, телеутов и кыргызов в Алтайско-Тяньшаньском регионе, а также казахов и ногайцев, в основном проживавших в Средней Азии [66, с. 83].

К той же «татарской» ветви А.Н. Самойлович отнёс вторую часть кодекса А. де Финале. Вдумчивые исследования первой части рукописи, предпринятые им, показали её принадлежность к кругу письменных памятников Золотой Орды, главный литературный центр которой находился в Хорезме. Характерной чертой, отличавшей золотоордынский тюрки от классического чагатайского языка была устойчивая тенденция к выпадению гуттуральных согласных на конце слова. Впрочем, сам Самойлович был склонен считать его смешанным языком, сочетавшим огузские и кыпчакские черты, и поэтому выделил в особую ветвь [66, с. 54, 60, 85, 91, 911-912, 937-940].

Даже смелее, чем В.В. Радлов, А.Н. Самойлович высказался в пользу происхождения народов-носителей языков «татарской» ветви от домонгольских кыпчаков. В рамках этой гипотезы он связывал с куманами генезис карачаевцев, малкарцев, кумуков и крымских татар (по его мнению, предки перечисленных народов осели примерно на нынешних местах обитания ещё до XIII века). В отличие от этих этнических групп, кочевники ещё в полной мере сохраняли своё племенное деление, учитывая номенклатурный состав которого, он соотнёс образование среднеазиатской группы с итогами монгольских завоеваний $[66$, с. 83,114$]$. В последующем Самойлович вернулся к более консервативным взглядам, обозначенным ещё И.Н. Березиным, и очень осторожно указал на то, что география распространения этих языков «почти целиком совпадает с пределами улуса Джучи, иначе именовавшегося Дешт-и Кыпчак». А к современному распределению турецких племён на этнографической карте привело произошедшее в XIII веке образование монгольской империи, внёсшее серьёзные коррективы в классификацию тюркских языков [66, с. 90-91, 901].

Однако ближайший из преемников А.Н. Самойловича, Н.А. Баскаков отнёсся несколько поверхностно к содержанию проблемы генезиса «кыпчакских языков», благодаря чему предложенная им интерпретация идей, высказанных в разное время предшественниками этого исследователя, приобрела характер механической компиляции. Баскаков объединил обе предложенные 
точки зрения и пришёл к выводу, что «основное ядро населения Золотой Орды» якобы составляли именно кыпчакские племена, а окончательное обособление их языка в отдельную ветвь было связано с выделением улуса Джучи из монгольской империи в XIII-XV вв. $[10$, с. $143,145,155,164]$. Впрочем, тезис об оформлении среднеазиатской группы «татарской» ветви тюркских языков в результате монгольских завоеваний он также принял $[10$, с. 16-17, $19,142-143,164]$. В те годы в отечественной историографии широко распространились представления о ведущей роли кыпчаков в истории Золотой Орды, к несостоятельности которых внимание учёных только недавно привлёк В.П. Костюков [10, с. 142,$145 ; 38$, с. 234].

В классификацию Самойловича Н.А. Баскаков счёл возможным внести некоторые поправки. В частности, алтайско-тяньшаньскую группу он вообще исключил из состава «татарских» языков, что мотивировалось в основном его желанием указать на связь между тяньшаньскими кыргызами и енисейскими (современными хакасами и шорцами), хотя бы и вопреки генетическим характеристикам [10, с. 207-219]. Однако другое внесённое им уточнение носило принципиальный характер. Из восточноевропейского ареала он выделил языки татар и башкир в особую волго-уральскую группу [10, с. 142-164]. Языки же карачаевцев и малкарцев, кумуков, крымских татар, караимов, рукописи А. де Финале, тюркских документов подольских армян, и даже арабографических тюркских памятников Египта он объединил в крымско-кавказскую группу, связывавшуюся им с домонгольскими куманами [10, с. 145-155].

При этом Баскаков обратил внимание на недостаточную обоснованность той части классификации Самойловича, которая касалась хорезмского языка тюрки, и отнёс его к чагатайской ветви [10, с. 170-178]. Но его несколько поверхностный подход выразился в том, что применительно к первой части кодекса А. де Финале Баскаков неожиданно буквально интерпретировал предложенный Самойловичем термин «огузо-кыпчакский язык», и склонен был объяснять её отличие от последующего текста кодекса языковым влиянием конфедерации огузских племён карабёркли, вошедшей в кыпчакский союз [10, с. 146].

В последней четверти XX в. отечественные тюркологи приступили к написанию сравнительно-исторической грамматики тюркских языков, обобщив в ней основные достижения в области их классификации. Ранее Н.А. Баскаков объявил одной из актуальных задач языкознания установление связи между событиями политической истории и процессом образования отдельных тюркских языков [10, с. 14-20]. Поскольку, однако, его собственные реконструкции нельзя было назвать вполне удачными, в одном из ранних томов грамматики Н.3. Гаджиева высказала сомнение в самой правомерности подобных сопоставлений [71, с. 3]. Но впоследствии авторский коллектив возвратился к попыткам внедрить лингвогеографический подход и связать языковую карту с основными этапами политической истории тюрков $[69$, с. 3$]$.

К.М. Мусаев по каким-то личным соображениям считал, что «татарская» ветвь оформилась уже в первом тысячелетии до н.э., хотя даже древнетюркские рунические надписи не сохранили следов существования генетически схожих диалектов. «По крайней мере, на рубеже христианской эры», по его мнению, от её праязыка в результате лингвистических контактов с болгарами и кыргызами отделились волго-уральская и алтайско-тяньшань- 
ская группы. Уже традиционной была его попытка связать историю крымскокавказской группы с куманами, но от утвердившегося мнения об образовании среднеазиатских языков в результате монгольских завоеваний он отказался, и попытался отнести их возникновение ко времени становления племени йимаков, с его точки зрения разделившегося с кыпчаками во II-VII вв. [69, с. 216217].

А.А. Чеченов придерживался вполне реалистичных датировок, но всётаки рискнул предположить, что генезис среднеазиатской группы связан не с итогами монгольских завоеваний, а с племенем канглов, входившим в кыпчакский союз. «После распада Золотой Орды» от канглыйского, как он считал, под болгарским влиянием отделились волго-уральские языки. Связь крымско-кавказской группы с куманами он не отрицал и даже считал генетически чуждые ей словоформы первой части кодекса А. де Финале кыпчакскими архаизмами. Зато алтайско-тяньшаньскую группу, под влиянием Н.А. Баскакова, исключил из числа «татарских» языков [69, с. 218-220].

О.М. Мудрак также сблизил алтайско-тяньшаньскую группу с кыргызскими, а не с «татарскими» языками, зато от остальных поправок Баскакова отказался и попытался внести уточнения в классификацию, используя методику глоттохронологии. Произведя сложные морфемостатистические подсчёты, из состава восточноевропейских языков классификации Самойловича он выделил кавказскую группу, объединяющую языки карачаевцев, малкарцев и кумуков. Особняком он поставил языки татар и караимов, так как посчитал, что башкирская морфология обнаруживает больше сходства со среднеазиатской группой (среднеазиатский субстрат объясняется включением в состав башкирского союза некоторых племенных общин ногайского происхождения) [69, с. 727, 732, 736].

Возникновение праязыка «татарской» ветви Мудрак, по личным соображениям, отнёс к эпохе владычества в Китае шестнадцати государств пяти северных племён [69, с. 737]. Так же как и Чеченов, он связал генезис среднеазиатской и восточноевропейской групп с размежеванием канглов и куманов. Это гипотетическое событие он отнёс ко времени вторжения Караханидов в Восточный Туркестан в 992 году. Кавказские языки отделились от татарского в его представлении после падения Хазарского каганата в середине XI в., а появление отдельных языков, таких как карачаевский, малкарский и кумукский, ногайский и казахский, казанский и мишарский диалекты татар, он попытался объяснить итогами золотоордынских поражений в войне с чагатайцами $[69$, с. 729,736$]$.

А.В. Дыбо была единственной из авторов грамматики, попытавшейся полностью отказаться от классификации А.Н. Самойловича. Вместо фонетических признаков она руководствовалась лексикостатистическими подсчётами, которые не обнаружили принципиальных различий между языками «татарской» и чагатайской ветвей. Такой результат был вполне предсказуем, учитывая то, что чагатайский ещё в первой трети XX в. использовался в качестве общетюркского литературного языка, и оказал устойчивое влияние на устные говоры «татарской» ветви. Однако она объединила их в одну общую ветвь, из которой так же как и Мудрак, выделила кавказскую группу, образовавшуюся, как она считала, в результате одной из «волн проникновения кыпчаков в Восточную Европу» около 780 г. [70, с. 766, 771, 815]. Разделение 
карачаевского, малкарского и кумукского языков она склонна была объяснять итогами монгольских завоеваний [70, с. 816].

Подводя итог изучению языков северокавказских тюрков виднейшими компаративистами, можно сделать предварительный вывод, что в болееменее окончательном виде классификация включающей их «татарской» ветви была разработана А.Н. Самойловичем. Несмотря на дальнейшие попытки создания оригинальных генетических схем в различных работах по сравнительно-историческому языкознанию, классификация Самойловича сохранила свою актуальность до наших дней, претерпев лишь незначительные изменения. Придерживающиеся её специалисты, при опоре на фонетические признаки, объединяют языки карачаевцев, малкарцев, кумуков и крымских татар, связывая, как правило, их происхождение с куманами.

Поскольку в противоположность европейской среднеазиатская группа частично охватила территории, находящиеся за пределами обитания исторических куманов, с самого начала было очевидно, что её генезис обусловлен результатами монгольских завоеваний. Поздние исследователи, однако, попытались приписать ей йимакское или канглыйское происхождение. Волгоуральская группа сформировалась под очевидным языковым влиянием средневековых болгар. Ещё более ощутимым оказалось субстратное воздействие енисейских кыргызов на алтайско-тяньшаньские языки, в связи с чем некоторые авторы настойчиво пытались объединить их с кыргызскими.

Значительно менее успешными оказались попытки ряда исследователей опереться при построении классификации на гипотетические методы глоттохронологии. Такие схемы до сих пор содержат слишком много фактических противоречий, и в них сделан акцент только на чрезвычайной лексической и морфологической близости карачаевского, малкарского и кумукского языков, которая не была секретом уже для этнографов середины XIX в.

\section{Проблема интерпретации старых памятников татарского языка.}

Соотнесение лингвистами генезиса «татарской» ветви с домонгольскими кыпчаками базируется, прежде всего, на исследованиях рукописи Антонио де Финале, составленной 11 июля 1303 [86, л. 1]. Между тем время написания этого кодекса примерно на два поколения отстоит от завоевания кыпчаков монголами в ходе западной кампании Бату. Кроме того, хотя в латинском тексте первой части рукописи, которая составлена в виде трёхязычного словаря, зафиксированный ею тюркский язык действительно назван «команским», во второй её части, содержащей различные тексты в основном религиозного содержания, ему присвоено наименование татарского [86, л. 1, 35 об., 61 об., 81 об.]. Чем можно объяснить такое противоречие?

Исходя из даты можно было бы скорее предположить, что рукопись А. де Финале была составлена для нужд священнослужителей Аквилонского викариата католической церкви, учрежденного на территории Улуса Джучи в XIII в. [29, с. 196]. Появление её конечной редакции в 1303 году, приходившемся на середину правления Токта-хана, можно объяснить большими надеждами, возлагавшимися на рукопись в деле пропаганды христианской религии, связанными с тем, что религиозная политика Токты, последнего немусульманского правителя Золотой Орды, отличалась широкой веротерпимостью. Уже при его преемнике Узбеке, принявшем курс на исла- 
мизацию Улуса Джучи, перспективы пропаганды христианства в нём значительно сократились $[30$, с. 88$]$. Поэтому новой тюркоязычной христианской литературы в Золотой Орде больше не появлялось, хотя сама католическая община Улуса Джучи продолжала существовать вплоть до времени его распада. Об использовании её членами в начале XV в. религиозных текстов, скорее всего, тождественных содержанию второй части рукописи, привёл отрывочные сведения И. Шильтбергер. Дав краткое описание Джулатской епархии, он отметил, что её кармелитские священники «молятся и поют потатарски» $[57$, с. $31-33]$.

Как уже упоминалось ранее, представителем «татарской» ветви является только язык второй части кодекса. Словарь в первой части не обнаруживает характерных «татарских» признаков. Между первыми двумя алфавитными разделами этой части кодекса уйгурским алфавитом вписано слово /bitik/ «письмо» [86, л. 30]. В латинской транскрипции оно встречается как в алфавитном, так и в двух тематических разделах кодекса [86, л. 25 об., 40 об., 45]. Слово в своём оригинальном написании, видимо, было пометкой, долженствовавшей напомнить составителю рукописи вписать глоссы к группе латинских слов раздела scriba, так и оставшейся без персидских и команских эквивалентов [86, л. 44]. Это может объясняться только тем, что оригинал памятника был выполнен на чагатайском языке.

В поисках подтверждений такого предположения автор обратил внимание на соответствие календарных циклов, сложившееся на момент составления словаря. В то время как таблица соотношения месяцев юлианского солнечного года и лунного года хиджры была составлена около 1292 года, зафиксированное совпадение месяцев года хиджры и солнечного календаря тюрков наблюдалось в 1286-1287 гг. ${ }^{1}$ [86, л. 36 об.]. В эти годы с первым и предпоследним месяцами татарского солнечного календаря совпали два месяца мусульманского лунного календаря, названиями которых составитель заменил их (см. таблицу I). Впоследствии европейские переводчики, транскрибировавшие названия месяцев в латинской графике, обратили внимание только на соответствие юлианского календаря текущим месяцам хиджры, не учтя того, что тюркский солнечный календарь начинался днём весеннего равноденствия. Всё это свидетельствует в пользу того, что в основу латинскоперсидско-команского глоссария лёг составленный несколькими годами ранее персидско-чагатайский словарь.

Таблица I

\begin{tabular}{|c|c|}
\hline $\begin{array}{c}\text { Месяцы арабского лунного } \\
\text { календаря }\end{array}$ & $\begin{array}{c}\text { Месяцы татарского солнечного } \\
\text { календаря }\end{array}$ \\
\hline Сафар & Safar ay (21.03-20.04) \\
\hline Раби’ аль-авваль & Sounz ay (21.04-21.05) \\
\hline Раби’ аль-ахыр & Ylias ay (22.05-21.06) \\
\hline Джумада аль-авваль & Tob ay (22.06-22.07) \\
\hline Джумада аль-ахыр & Songusax ay (23.07-23.08) \\
\hline Раджаб & Cux ay (24.08-22.09) \\
\hline
\end{tabular}

1 Тюркские народы использовали солнечный календарь, разработанный при сельджукском султане Мелик-шахе, в котором начало нового года приходилось на Науруз. Названия некоторых из перечисленных в кодексе месяцев сохранились в календаре крымских татар, караимов и карачаевцев [66, с. $255 ; 41$, с. 8]. 


\begin{tabular}{|c|c|}
\hline Ша'бан & Orta Cux ay (23.09-23.10) \\
\hline Рамадан & Sonchux ay (24.10-22.11) \\
\hline Шавваль & Ches ay (23.11-21.12) \\
\hline Зу-ль-ка'да & Orta Ches ay (22.12-21.01) \\
\hline Зу-ль-хиджжа & Curba(n) bara(m) ay (21.01-19.02) \\
\hline Мухаррам & Asuc ay (20.02-20.03) \\
\hline
\end{tabular}

Косвенное подтверждение этого вывода можно найти и в преамбуле рукописи. В то время как в тексте слева направо по порядку расположены столбцы на латыни, фарси и чагатайском языке, составитель указал лишь на то, что в рукописи персидский и команский содержатся по алфавиту [86, л. 1]. Тем самым он подразумевал, что лишь привёл оригинальный восточный материал в соответствие с алфавитным порядком латинского перевода. Эта формулировка видимо немного озадачила Я.Ф. Томмазини, который, присваивая библиографическое обозначение кодексу, латинский язык вопреки действительному порядку указал после персидского и команского. Контраст форм чагатайской лексики с записями живой татарской речи, содержащимися во второй части, добавленной к рукописи позднее, представлен в таблице II.

Таблица II

\begin{tabular}{|c|c|c|c|}
\hline \multirow{2}{*}{$\begin{array}{c}\text { Характерные } \\
\text { соответствия }\end{array}$} & $\begin{array}{c}\text { Персидско- } \\
\text { чагатайский } \\
\text { словарь }\end{array}$ & $\begin{array}{c}\text { Записки } \\
\text { миссионе- } \\
\text { ров }\end{array}$ & Значение \\
\hline \multirow{2}{*}{$1 . / \mathrm{k}, \mathrm{g} \sim \mathrm{w} /$ в ауслауте. } & bitic & bitiv & письмо \\
\cline { 2 - 4 } & sag & sav & здоровый \\
\cline { 2 - 4 } & tag & tav & гора \\
\cline { 2 - 4 } & yag & jav & жир \\
\hline \multirow{2}{*}{$\begin{array}{c}\text { 2./g w/ в интер-вокальной } \\
\text { позиции }\end{array}$} & agerla & avurla & славить \\
\cline { 2 - 4 } & agx & avz & рот \\
\hline \multirow{2}{*}{$\begin{array}{c}\text { 3. Редукция гуттуральных в } \\
\text { ауслауте }\end{array}$} & tixgi & tiz & колено \\
\hline
\end{tabular}

По вполне понятным причинам актуальна будет попытка пересмотреть интерпретацию упомянутого в рукописи этнонима коман, который привлек к себе внимание Клапрота. В XI-XIII веках он действительно употреблялся как европейское название племён кыпчакского союза [4, с. 208, 213-215, 233-240, $266-274,384,394,396-397$; 61 , c. $47-48,74-75,77-79$; 27, c. 117-120, 125$126,131-133,135,145-146,149,282-283$; 58, c. 37, 45-46, 50-52, 59-60, 63, $72,74,83-84,91,101,103,106-107,109,115,119-120,128,156,370 ; 62$, с. $215 ; 37$, с. $114-115,117-119,127-128 ; 55$, с. 446,504$]$. Но в литературе $\mathrm{XIV}-\mathrm{XV}$ вв. название Кумания стало в основном использоваться в качестве альтернативного синонима географических терминов Татария и Солдания $[25$, c. $6-7,124,150 ; 31$, с. 13]. А к рубежу XVI-XVII вв. слово куман уже полностью сменило своё первоначальное этнографическое содержание, и свободно употреблялось в значении «татарин» [64, с. 113-114]. В результате интеграции кыпчаков в состав Улуса Джучи тенденция к исчезновению грани между этими этнонимами в европейской литературе, видимо, наметилась уже при жизни Плано Карпини, который упомянул о «команах из числа татар» 
[58, с. 83]. Впрочем, такие авторы, как Дж. дель Плано Карпини, Г. де Рубрук, П. де Витториа и Ф. Пеголотти придавали понятию «язык куманов» нарицательное значение, подразумевая под ним любой тюркский язык, который они различали с родным языком монголов. Они также считали куманский языком среднеазиатских мусульман, и указали, что он использовался для письма уйгурским алфавитом, да и сами корни языка куманов и турков эти авторы связывали с уйгурами [58, с. 37, 50, 74, 128, 156; 92, с. 232, 291].

Помимо прочего в пересмотре также нуждается традиционное истолкование загадки о птичьем молоке, упоминающей Кыпчак, содержащейся во второй части кодекса А. де Финале, которую некоторые исследователи сочли доводом в пользу «куманской» принадлежности его языка [38, с. 209-210]. Загадка гласит se(n)da, me(n)da joh, se(n)gir tavda joh, Utlu tasda joh, Kipcakda joh, что в переводе означает «нет ни у тебя, ни у меня, ни в горах, ни в Утлу тазе, ни в Кыпчаке» [86, л. 60]. Нетрудно заметить что в загадке местоимения «у тебя» и «у меня» представлены в виде антитезы друг другу, а горы и Утлу таз противопоставлены Кыпчаку. Название Отлы таз носила местность (возможно населённый пункт), распологавшаяся в Керченском эле, и отделённая проливом от области Кыпчак [21, с. 121]. Последнее наименование принадлежало одному из вилайетов Золотой Орды, которому мусульманские литераторы, писавшие в эпоху после монгольских завоеваний, также часто присваивали персидское определение Дешт-и Кыпчак, «кыпчакская степь» [3, с. 213; 24, c. $120 ; 21$, c. $123 ; 30$, c. $86,97,98,101,165,219,242,250,252,267,269 ; 57$, c. 56-57; 9, с. 401, 408]. По-видимому загадка была сочинена в ситуации, когда её автор, находившийся на берегу Керченского пролива, вынужденно обозначил в ней географическую номенклатуру близлежащих территорий.

Разумеется надежды филологов разыскать описание кыпчакского языка не ограничились одним лишь изучением кодекса А. де Финале, и были привлечены к ряду арабографических тюркских произведений, написанных на Ближнем Востоке после монгольских завоеваний. Но эти памятники оказались генетически очень близки к «персидско-команскому» словарю, и так же как и он, демонстрировали чагатайскую литературную традицию $[66$, с. 59 , $903,912,927 ; 10$, с. 8-10, 56-58, 147]. Единственное аутентичное описание наречия домонгольских кыпчаков удалось обнаружить в Диване Махмуда алКашгари, и это открытие сделало вероятность лингвистической преемственности от кыпчаков к языкам «татарской» ветви довольно проблематичной. Недавние исследования Д.М. Насилова показали, что Махмуду ал-Кашгари были знакомы два различных кыпчакских наречия.

Речь племени канглов, обитавшего в Средней Азии (бывшего крыла печенегов, присоединившегося к кыпчакскому союзу [1, с. 11-12]) носила характерные огузские черты, резко отличавшие её от «татарских» языков. Например «татарским» фонемам $/ \mathrm{m} /$ и $/ \mathrm{t} /$ в начале и отчасти на конце слова соответствовали канглыйские $/ \mathrm{b} /$ и $/ \mathrm{d} /$. Кроме того в речи канглов были менее устойчивы гуттуральные согласные, а в инициальной позиции они всегда использовали сонант /j/ вместо аффрикаты /dž/. Генетические признаки говора волжских кыпчаков, описанного ал-Кашгари, наоборот, сближают его с кыргызской ветвью тюркских языков. В противоположность своим среднеазиатским собратьям, в начале слова кочевники Поволжья всегда употреб- 
ляли звук /dž/ вместо /j/, а в интервокальной позиции заменой канглыйскому /j/ служило более архаичное /z/ [52, с. 291].

Как известно, до монгольских завоеваний территория кочевой конфедерации кыпчаков занимала берега Дона, Волги и Яика, и именно тем, что в бассейне этих трёх рек, «других илей, кроме кыпчакского, не было», объясняется присвоенное впоследствии этому региону название, «Дешт-и Кыпчак - Кыпчакская степь» [63, с. 44]. Разумеется, оригинальную кыпчакскую ономастику, если только она хотя бы отчасти сохранилась, следует искать в пределах этой самой территории. Характерное для кыпчакской лексики, как указал ал-Кашгари, слово /azaq/ оказалось засвидетельствованным в золотоордынской топонимике [47, с. 71]. В начале XIV в. Золотоордынский хан (как предполагается, Токта) основал город Азак, название которого было обусловлено его местоположением в «устье» Дона [66, с. 54; 8, с. 313]. Благодаря тому, что название местности было присвоено не самими татарами, а перенято ими от коренного населения, в разговорном татарском языке оно произносилось /Azaw/, в то время как его закономерным татарским эквивалентом было бы слово /ajaq/ (речь идёт о современном городе Азов) [81, с. 63].

Как представляется автору этих строк, на позицию многих современных исследователей проблем преемственности кочевых племён определяющее психологическое воздействие оказала широкая репрезентативность этнонима кыпчаки в родовой номенклатуре народов «татарской» языковой ветви, которая в значительной степени могла сложиться под влиянием идентичного наименования одной из крупнейших единиц принятого монголами административно-территориального устройства. При этом практически был обойдён вниманием тот факт, что этноним куманы, под которым кыпчакская конфедерация фигурирует в западноевропейских источниках, сохранился в Новое Время на Алтае (ныне употребляется исключительно в сочетании с суффиксом -ды). Между тем, язык племени кумандинцев принадлежит к кыргызской ветви и сохранил основные фонетические черты говора волжских кыпчаков, описанного Кашгари [10, с. 197, 213-218].

В завершение темы следует упомянуть, что название вилайета Дешт-и Кыпчак прочно вошло в официальную титулатуру золотоордынских, а затем и крымских ханов $[30$, с. 94-96, 98, 100, 105-109, 118, 120-121, 154, 165, 168, $193-194,200-201,214,218,221,252,254$; 68, с. 83, 85-87, 93, 173, 245, 259; 28 , с. $182 ; 39$, с. $65 ; 78$, с. 23$]$. Благодаря этому термин «кыпчакский язык» в мусульманской литературе превратился во второе название татарского [30, c.104, 110; 84, с. 115]. В частности, османские турки до недавнего времени сохраняли практику наименования татарского языка «кыпчакским» или «дешти» (степным) [29, с. 116; 66, с. 62, 936].

Относительно поздно в поле зрения специалистов попали документы XVIXVII вв., принадлежавшие армянским общинам Львова и Каменца-Подольского, и еврейско-караимским Луцка, Галича и Трок, и составленные на языке литовских татар [66, с. 910, 921]. В армянских документах язык золотоордынцев носил уже традиционное двоякое название - татарского и кыпчакского [14, c. 11]. Но в конце первой трети XX в. в Советском Союзе было сокращено преподавание османской и чагатайской литературы, поэтому к тому времени, как началось изучение армянских документов, «дешт-и кыпчакская» номенклатура татарского языка была знакома лишь немногим ориенталистам. Неудивитель- 
но, что в этом термине исследователи стали искать ещё один аргумент в пользу преемственности «татарских» языков от кыпчаков.

Разумеется от внимания лингвистов не укрылась тождественность тюркского языка армянских и еврейских документов [66, с. 910, 921; 79, с. 29]. Евреи называли его кедарским ${ }^{2}$, в соответствии с традиционным обозначением тюркских языков в иудаистской литературе [48, с. 576]. Однако благодаря тому, что кыпчакам, так же как и остальным тюркам, евреями ранее было присвоено нарицательное имя кедаров, предпринимались попытки связать эти языковые памятники именно с ними [40, с. 263-267]. Впрочем, в Крыму язык литовских татар был более известен под простонародным названием чалтайского [75, с. 41-48]. Происхождение этого термина связано с переданным в 1440-х гг. золотоордынцами Великому княжеству Литовскому туменом Еголдая Сараева, который стал самым крупным объединением татар в составе этого государства $[11$, с. 58]. Тем не менее лингвисты пытались непосредственно соотнести проблему генезиса литовско-татарского языка с историей еврейских и армянских колоний в Польше и Литве, изучение которой было затруднено из-за ряда целенаправленных фальсификаций${ }^{3}$.

2 Эквивалент широко распространённого христианского наименования татар «агаряне» или «измаильтяне» $[55$, с. $521 ; 56$, с. 779, 894] (в Библии Агарь - мать Исмаила, а Кедар - его второй сын) [Быт. 16: 1-16; 25: 12-18].

В XIX в. процветала религиозная дискриминация, с поиска способов оградить от которой своих единоверцев началась деятельность первого караимского исследователя А.С. Фирковича. Ради этого он предпринял оригинальную попытку доказать их непричастность к казни Христа, осуществив комплексную правку дат на собранных им рукописях и надгробных эпитафиях, с помощью которых стремился продемонстрировать, что евреи-караимы поселились в Крыму сразу после вавилонского пленения и поэтому не могли участвовать в его распятии [16, с. 430-431; 79, с. 17-18]. Для того чтобы обогатить свой замысел красочными деталями, Фиркович сфальсифицировал находку погребения Исаака Сангари, якобы «караимского раввина, обратившего хозар в иудейскую веру» $[15$, c. 111-113; 45, с. 391]. Творчество Фирковича произвело столь сильное впечатление на некоторых ориенталистов, что один из них, В.В. Григорьев, восприняв всерьёз его схоластические приёмы, даже высказал гипотезу о хазарском происхождении караимов [20, с. 433-435]. Впоследствии фальсификации Фирковича были выявлены А.Я. Гаркави [15, с. 98-121]. Но статус евреев в XX веке по-прежнему служил объектом дискриминации. Так как с самого начала караизм противостоял ортодоксальному иудаизму, основанному на талмуде, религиозный руководитель караимов С.М. Шапшал попытался обойти сегрегацию, приняв на вооружение точку зрения Григорьева. Тем самым он преследовал цель отказаться от еврейских корней и доказать тюркское происхождение караимов [79, с. 18-19]. Таким образом родилась тенденция связывать использовавшийся евреями-караимами татарский язык с их мнимым хазарским происхождением. В этой связи следует разъяснить, что первоначально среди хазар получило распространение христианство, но современник халифа Харуна ар-Рашида хазарский царь Обадия действительно принял иудаизм [48, с. 567-573; 9, с. 598]. Иудаизм был принят им в уже сложившейся раввинистической форме, о чём повествует письмо хазарского царя Иосифа Хасдаю ибн Шапруту, извлечённое самим же А.С. Фирковичем из Каирской генизы [36, c. 80, 97]. Основатель же караизма Анан Ганаси бен Давид в годы правления Харуна арРашида только приступил к изложению основ своего вероучения [79, с. 36-37]. До X в. доктрина караизма переживала своё становление, завершившееся консолидацией общины караимов в Иерусалиме. После его захвата крестоносцами в конце ХІ столетия, её последователи вынуждены были перебраться в Византию [79, с. 37-38]. Именно с границами византийского княжества Феодоро связаны старые караимские памятники в Крыму [45, c. 137, 390-391]. Первые сведения о крымских караимах оставил при описании событий 
В связи с изложенным целесообразной будет небольшая справка по истории колоний татар, евреев-караимов и армян в Польско-Литовском государстве. Причиной притока в него основной их массы послужила разгоревшаяся в последние годы XIV в. война за золотоордынский престол между ханами Токтамышем и Тимур-Кутлугом. В её ходе Токтамышу оказал поддержку великий литовский князь Витовт, который в 1398 году вторгся в Крым и после сражений под Каффой и Солхатом переселил в Литву захваченных в них татар. Поскольку в 1399 г. войска Витовта были разбиты Тимур-Кутлугом в генеральном сражении на р. Ворскле, уведённые крымцы навсегда остались в великом княжестве Литовском [79, с. 27-28, 158; 68, c. $147-154 ; 49$, с. $133-134 ; 46$, с. $91,103-104,254]$.

Первым документальным свидетельством присутствия армян в Каменце является памятная запись об основании григорианской церкви святого Николая как раз в 1398 г. [23, с. 37; 67, 45-46]. Служебник, пожертвованный в этом году церкви её строителем Синаном, сыном Хутлубея, был написан в 1349 году в «Сурхате» и там же приобретён им в 1394 г. [50, с. 180; 67, 4445]. Судя по дарственной надписи, в 1394 г. Синан ещё жил в Солхате. В частности, из ханских ярлыков известно, что в городах крымского вилайета обитало смешанное население из армян, евреев и мусульман-татар [66, с. 234; 68, с. 118-119]. Очевидно в 1398 г. Витовт вместе с татарами переселил из Солхата и его армянских и еврейских жителей (в научной литературе даже называлось точное число выселенных им из Крыма караимских семей - 383) $[16,1895$, c. $430 ; 20$, c. 433$]$.

Впрочем, некоторые колонии татар и армян на территории будущего Польско-Литовского государства возникли ещё в эпоху расцвета Золотой Орды. Например, такая диаспора существовала в Галиции. Известно, что вскоре после того как польский король Казимир III в 1349 г. захватил у золотоордынцев её центр г. Львов, он посчитал необходимым даровать актом 1356 г. самоуправление обитавшим в этом городе общинам армян, евреев и сарациновтатар ${ }^{4}$. Татары занимали северную часть города, благодаря этому получившую

конца XII в. Петахия Регенсбургский [40, с. 266-267]. Тогда же появилась в Крыму и армянская диаспора (из её среды вышли правители княжества). В XIII в. греческое, армянское и еврейское население княжества попало под власть монголов.

${ }^{4}$ Проблематичность изучения истории армянских колоний в Польско-Литовском государстве связана с событиями 1641 г., когда в Литовскую Метрику была внесена запись, адресованная «от великого князя Федора Дмитровича» «ко согацким армянам», и датированная 1062 г. Хотя в записи упоминалось только искажённое название Солхата в Крыму, а названное в ней лицо не поддаётся идентификации, в XVII-XVIII вв. сложилась устойчивая традиция связывать с ней основание армянской колонии в Каменце. В XIX-XX вв. большинство исследователей, несмотря на неопределённость записи, считали всё-таки возможным отнести основание армянской колонии к XIII столетию. Только Я. Дашкевич обратил внимание на беспочвенность всех связанных с этой записью выводов [22, с. 50]. Первым упоминающим армянскую колонию польским документом является грамота короля Казимира III 1356 г., дарующая городу Львову Магдебургское право [32, с. 16-17]. Однако с эти документом связан ряд недоразумений. С. Рошка каким-то образом отнёс её содержание к Каменцу и под 1350 г. указал, что «каменецкие армяне в этом году начали по привилегиям польских королей вершить суд» [22, с. 55-56]. Похожую ошибку совершил ранее М. Бжишкян, который считал, что «Казимир Великий дал грамоту армянам Каменца в 1344, а потом Львовянам в 1356 году, предоставив им власть и право иметь отдельный суд» $[22$, с. 55]. В первой грамоте, описанной М. Бжишкяном (видимо, по 
название Татарского предместья. Между прочим, автор «Рисале-и Татар-и Лех», специального сочинения, посвящённого истории литовских татар, посчитал необходимым упомянуть о татарском населении, осевшем на территории Речпосполиты в середине XIV века. В этой связи он отметил, что ещё до переселения Витовтом крымцев в Литву, «во времена благочестивого Джаны-бека бывали нашествия татар на Польшу, во время которых несколько отрядов из татарских племён поселились в этом государстве» [68, с. 147].

Сохранились сведения, что современные Витовту крымские армяне широко употребляли татарский язык [31, с. 15]. Дальнейшее его использование в среде переселённых из Крыма колонистов было продиктовано территориальным соседством общин армян и караимов с поселениями литовских татар. После основания главной колонии караимов в Трокском воеводстве, неподалёку от первых селений литовских татар, в Польско-Литовском государстве появились ещё две их диаспоры [49, с. 90, 133-134; 46, с. 109]. Первая возникла после расселения части татар на Волыни (под неё была отведена часть г. Луцк) [49, с. 134; 79, с. 27]. Вторая образовалась при Татарском предместье г. Львова, затем была переведена за город в местечко Кукизов, а оттуда, в конечном счёте, в Галич. С первой четверти XVI в. Начался «золотой век» литовско-татарского языка, на котором с этих пор велась армянская и еврейская канцелярия [14, с. 14]. Лишь к концу XVII в. процесс полонизации привёл к забвению тюркской речи в среде литовских татар и армян, и только более замкнутая еврейская община сохранила их разговорный язык до наших дней в качестве живого наречия корпорации караимов.

Итак, в памятниках оригинальной тюркской литературной традиции прежде всего привлекает к себе внимание её чрезвычайная консервативность, благодаря которой сами золотоордынские татары не оставили живых записей своего языка, а его ранние фиксации пришлось выполнить иноземцами. В первые годы XIV в. такую задачу взяли на себя католические священнослужители Аквилонского викариата, прибывшие из Западной Европы. А несколько позже, в XVI в., он превратился в язык канцелярии живших среди крымских и литовских татар и обслуживавших их торговые потребности армян и евреев. В восточной литературе сложилась традиция именовать золотоордынскую речь татарским, а также кыпчакским или дештийским языком. Отчасти в связи с последним обозначением в современном языкознании предпринимаются периодические попытки смешать его памятники с языком племен кыпчакского союза, который, как выясняется в действительности, делился на диалекты, генетически связанные с огузской и кыргызской, а не с «татарской» ветвью.

неисправному списку), нетрудно узнать акт Магдебургского права, действительно дарованный Каменцу-Подольскому в 1374 г. литовскими князьями Юрием и Александром Кориатовичами [50, с. 207-209]. В ней, однако, армяне не упоминаются. Но подтверждая Магдебургское право Каменцу-Подольскому в 1432 г., Владислав Ягайло уже даровал им торговые привилегии, разрешавшие торговать сукном и другими товарами [50, с. 380]. В 1443 г. эти торговые привилегии были подтверждены Владиславом Варненьчиком [50, c. $210 ; 22$, с. 56]. Грамота 1374 г. сроком действия в 20 или 24 года, конечно же, не затрагивала прямо права армян, поселившихся в Каменце в 1398 г. 


\section{Периодизация истории «татарских» языков}

Убедившись в безосновательности попыток связать проблему происхождения тюркских обществ Северного Кавказа с кыпчакским союзом племён, можно разбить вопрос их генезиса на три этапа, соответствующих определённым лингвистическим событиям. Это, прежде всего, образование «татарской» ветви тюркских языков, затем отделение её крымско-кавказской группы и, наконец, обособление самих языков горских обществ. Внимание лингвистов неоднократно привлекала связь «татарской» ветви с границами Улуса Джучи. А вот проблема образования её региональных групп осталась мало разработанной.

Дело в том, что до сих пор не сложилось единой трактовки чисто языковых проблем генезиса крымско-кавказской группы. Сам автор подробной генеалогической классификации А.Н. Самойлович не выделял её из числа остальных родственных восточноевропейских языков, которые от среднеази-

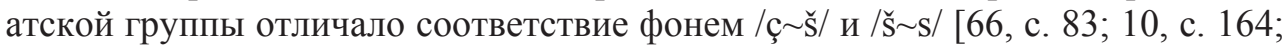
69, с. 269-271]. Позже Н.А. Баскаков обратил внимание на различие вокалического строя крымско-кавказских и волго-уральских языков [10, с. $145,156-$ 157]. Эта концепция получила дальнейшее развитие в сравнительноисторической грамматике, авторы которой вообще сочли систему вокализма основным эталоном принадлежности к той или иной группе «татарских» языков [69, с. 219-221, 253-259]. Отметив, что среднеазиатский вокализм представляет собой тип, переходный между крымско-кавказским и волгоуральским, А.А. Чеченов был склонен сближать языки кочевников Средней Азии и жителей Поволжья [69, с. 220]. К.М. Мусаев, наоборот, по тем же соображениям предполагал особую близость среднеазиатской и крымскокавказской группы [69, с. 217].

Впрочем, едва ли эти точки зрения удачно сочетаются с предположением А.А. Чеченова об относительно позднем возникновении вокалических различий между отдельными группами [69, с. 255-258]. Вероятно, консонантные особенности среднеазиатской группы следует признать её более характерными признаками. Если взять за основу периодизации первоначальную классификацию Самойловича, то границы диалектных зон почти точно совпадают с административным делением Золотой Орды. Её краеугольным камнем стали земли Сибири и Средней Азии, завоёванные в начале XIII в. Джучи, старшим сыном Чингиз-хана. После смерти Джучи в 1227 г. они были унаследованы старшим из его детей Ордой [73, с. 198-202, 217, 221-223]. Однако чуть позже главными владениями Джучидов стали всё-таки территории Восточной Европы, покорённые Бату, младшим братом Орды, во время похода 1236-1242 гг. [73, с. 202-203, 206-211]. Поскольку Орда уступил верховную власть брату, их домены получили в соответствии с традиционной цветовой символикой тюркомонгольской крыльевой иерархии наименования Синей и Белой Орды [77 c. 344-346, 349-350]. Несмотря на то, что верховенство принадлежало именно потомкам Бату, оба юрта управлялись раздельно [73, с. 227-228].

$\mathrm{B}$ XV в. благодаря политической деятельности Абу-л-Хайр-хана «Синяя Орда» обрела независимость от главного юрта, но вскоре центробежные тенденции привели к её распаду. В результате составлявшие её кочевые племена образовали несколько государств, такие как Казахское ханство, юрты Шибанидов в Хиве, Бухаре и Сибири, а также Ногайская Орда [33, с. 24-29]. Но в 
начале XVI в. персидский автор Фазл Аллах ибн Рузбихан Исфахани ещё застал время, когда население всех этих этнополитических образований считалось одним народом кочевых узбеков [80, с. 62]. К концу того же столетия несколько ногайских племён образовали отдельный союз каракалпаков. Итак, можно считать вполне установленным тот факт, что все носители среднеазиатской группы «татарских» языков являются выходцами из Синей Орды, левого крыла Улуса Джучи. К их числу принадлежат казахи, ногайцы, каракалпаки и небольшой этнографический костяк современных узбеков (от которого последний политоним был перенят более многочисленным населением бывшей западной части Чагатайского улуса).

Впрочем, наречие населения сибирской части Синей Орды видимо несколько отличалось от среднеазиатского. Так, если вокализм языка сибирских татар и кочевников Средней Азии в целом схож, то консонантизм первого ближе к восточноевропейскому. Последняя черта также характерна для алтайско-тяньшанской группы, которая, однако, унаследовала от языка енисейских кыргызов его специфический гласный строй.

После отделения среднеазиатских владений в борьбу за престол Белой Орды вступили несколько конкурентов, каждый из которых стремился добиться консолидации её земель под собственной эгидой. Последним её титулованным правителем был Улуг-Мухаммад-хан [11, с. 68]. После его смерти в 1445 г. основная часть юрта Бату, известная с этого времени под именем Большой Орды, перешла в руки его основного соперника Кючюк-Мухаммада [33, с. 20-22]. Тем не менее прямым наследникам старшего из двух тёзок удалось сохранить за собой некоторые периферийные территории, что фактически означало распад Белой Орды. Так к 1448 г. его племяннику ХаджиГирею удалось утвердиться в Крымском вилайете [11, с. 67; 68, с. 183-199; 33 , с. 18-20; 79, с. 160-161]. Его старший сын Махмудек в 1445 г. захватил Булгарский вилайет, территория которого затем составила Казанское ханство $[11$, c. $63-64 ; 33$, с. $12-15 ; 60$, с. 52-54]. Второй сын Касим поступил на службу к великому Московскому князю, получив от него в кормление Мещеру $[11$, с. $65 ; 33$, с. $15-17 ; 60$, с. $57 ; 74$, с. $4-7]$. А спустя столетие и сама Казань была покорена Москвой, после чего некоторые кочевые племена аннексированного ханства образовали башкирский союз.

Именно территория Казанского ханства и смежной с ним Мещеры образует ареал обитания народностей казанских татар, мишарей и башкир, языки которых составляют волго-уральскую группу. Сложившаяся лингвистическая ситуация объясняется тем, что после того, как отколовшиеся от Орды кочевники-татары заняли Булгарский вилайет, начался вынужденный процесс их перехода к оседлости, приведший к смешению с коренным тюркским населением среднего Поволжья, результатом которого был унаследованный татарами от болгар языковой субстрат [33, с. $12-14,38,60 ; 69$, с. 255-258]. Напротив, крымско-кавказская группа включила те татарские говоры, которые не подверглись глобальному внешнему влиянию, и сохранили более архаичные черты, присущие разговорному языку Белой Орды. В частности, к ней принадлежал язык литовских татар, эмигрировавших из Орды ещё до её распада.

Поскольку территория Северного Кавказа, на которой расположились впоследствии интересующие нас общества, входила на протяжении XV в. в состав Большой Орды, следует специально остановиться на её судьбе. Её 
конец наступил, когда в 1502 году она была разгромлена крымцами, после чего внуки Кючюк-Мухаммада временно вступили в конфронтацию друг с другом. Сыновьям большеордынского хана Махмуда удалось консолидировать остатки татар вокруг её бывшей столицы Астрахани, в то время как дети его брата Ахмада обосновались в другом большеордынском городе, Тюмени, располагавшемся в устье Терека. Однако, в 1515 г. и он был включён в состав Астраханского ханства $[29$, с. $58-62,74-75,208-209 ; 33$, с. 22 24; 42 с. 440-445]. Продолжив противостояние с крымцами, Астрахань в 1547 г. была ими разрушена и очищена от населения, которое было угнано в Крым, а восстановленный город вскоре заселили переправившиеся из-за Волги ногайцы $[29$, с. $139-142,154,222-223 ; 17$, с. 150]. Тюмень в результате этих событий к 1550 году признала власть правителя лакцев, Будай-шамхала. После присоединения Астраханского ханства к России и занятия Тюмени в 1558 г. русскими войсками, её жители переселились на Сулак. Попав под власть шамхала, резиденция которого располагалась в селении Кумук, тюменцы приняли название этого аула в качестве политонима $[29$, с. 155,157 ; 42 , c. $444-445 ; 65$, с. $266,276-277]$.

Предпринятый в этой работе сравнительно-исторический анализ демонстрирует существование лингвистической преемственности между кочевниками Белой Орды, и народами-носителями крымско-кавказской группы «татарских» языков. Существенной особенностью этой группировки диалектов являлось её использование в Крыму и Литве в качестве языка межнационального общения, так как от кочевых племён татарский язык переняли местные диаспоры евреев-караимов и крымчаков, греков-урумов и армян. Впрочем, ордынское происхождение исповедующих ислам народов этой диалектной зоны, таких как карачаевцы, малкарцы, кумуки и крымские татары, не вызывает каких-либо серьёзных сомнений. Некоторые лексические и морфологические особенности языка горских обществ Центрального Кавказа, которые сближают его с кумукской речью, используемой выходцами из Астраханского ханства, но отличают от говора крымских и литовских татар, видимо, сохранились как следы непосредственного происхождения тюркских жителей Центральной части Кавказа от кочевников Большой Орды или Астраханского ханства.

Что касается дивергенции современных крымско-кавказских языков, то она в значительной мере была обусловлена локальным языковым субстратом и адстратом. Развитие принадлежащих к этой группе диалектов происходило по одному из двух альтернативных путей. Так говоры малкарского горского общества, а также галицко-луцкой и тракайской диаспор караимов, благодаря языковому окружению осетин-дигорцев, славян и литовцев переняли некоторые черты свойственные индоевропейской фонетике [69, с. 250, 253, 271, 286,$298 ; 83$, с. 42-43]. Крымский и кумукский языки, наоборот, под османским и сефевидским владычеством испытали сильное огузское влияние ${ }^{5}$ $[68$, c. $52 ; 66$, c. $114-115 ; 10$, c. $117,151,154-155 ; 69$, c. $217 ; 79$, c. $147-149]$.

${ }^{5}$ В 1475 г. Османская империя захватила южный берег Крыма, после чего приняла сюзеренитет над Крымским ханством [68, с. 214-244; 79, с. 161-162; 33, с. 129]. В сходном положении оказался Дагестан, валии-шамхалы которого присягнули в вассалитете Сефевидам $[18$, с. $71-72 ; 13$, с. 191,$222 ; 82$, с. 55]. После этого из Персии в него переселились туркменские колонисты, частично смешавшиеся с кумуками [19, с. 257; 17 , c. $166 ; 13$, с. $227-228,373 ; 44$, c. $12-13 ; 54$, c. $39-40 ; 53$, с. $81-82]$. 
Остаётся констатировать, что в XIII в. монгольские завоевания вызвали резкую смену лингвистической карты Восточной Европы и Средней Азии. В предшествующую эпоху над степями, протянувшимися вдоль границы этих двух регионов, господствовал кыпчакский союз племён, использовавший тюркские языки, принадлежавшие к кыргызской и огузской ветвям. Записи европейских миссионеров показывают, что к началу XIV в. их вытеснила «татарская» ветвь тюркских языков, сформировавшаяся в пределах Улуса Джучи. Возможно, на генезис золотоордынских говоров оказал какое-то влияние распространённый среди татар ещё в XI в. тюркский язык, который по фонетическим признакам был к ним достаточно близок [47, с. 70-71]. Другой его вероятной преемницей является чагатайская языковая ветвь, которую с татарской связывает ближайшее родство. Впрочем, не располагая более подробным описанием языка татар XI в., судить о степени такой преемственности затруднительно. В XV в. распад Золотой Орды привёл к разделению «татарских» языков на несколько групп, одна из которых дала начало наречиям горцев Северного Кавказа.

\section{СПИСОК ЛИТЕРАТУРЫ}

1. Абдуманапов Р.А. Культурно-историческая основа кыргызского племенного образования кангды // Тюркологический сборник 2005. М., 2006. С. 6-20.

2. Абрамович A. Очерк сословного строя в горских обществах Терской и Кубанской областей // Сборник документов по сословному праву народов Северного Кавказа. Нальчик, 2003. Т. 1. С. 19-72.

3. 'Аджаи’иб ад-дунйа (чудеса мира). М., 1993.

4. Анна Комнина. Алексиада. СПб., 1996.

5. Анучин Д.Н. Россия в этнографическом отношении // Энциклопедический словарь Россия. СПб., 1991. С. 139-152.

6. Аристов Н.А. Заметки об этническом составе тюркских племен и народностей // Живая старина. СПб., 1896. Вып. III-IV. С. 277-456.

7. Бакиханов Аббас-Кули-ага. Гюлистан-и Ирам. Баку, 1991.

8. Бартольд В.В. Работы по исторической географии. М., 2002.

9. Бартольд B.B. Работы по истории и филологии тюркских и монгольских народов. М., 2002.

10. Баскаков Н.А. Тюркские языки. М., 2006.

11. Беспалов P.A. Хан Улу-Мухаммед и государства Восточной Европы: от Белёва до Казани (1437-1445) // Золотоордынская цивилизация. 2012. Вып. 5. С. 53-70.

12. Бларамберг И.Ф. Историческое, топографическое, статистическое, этнографическое, и военное описание Кавказа. М., 2010.

13. Броневский C.M. Новейшия Известия о Кавказе, собранныя и пополненныя Семеном Броневским. СПб., 2004.

14. Гаркавец А.Н. Кыпчакское письменное наследие. Каталог и тексты армянским письмом. Алматы, 2002. Т. 1.

15. Гаркави А.Я. По вопросу о иудейских древностях, найденных Фирковичем в Крыму // Журнал Министерства народного просвещения. СПб., 1877. Ч. СХСІІ. C. $98-121$.

16. Гаркави А.Я. Караимы // Брокгауз Ф.А., Ефрон И.А. Энциклопедический словарь. СПб., 1895. Т. 14. С. 426-432.

17. Георги И.Г. Описание всех обитающих в Российском государстве народов. СПб., 2007. 
18. Гербер И.Г. Записки о находящихся на западном берегу Каспийского моря, между Астраханью и рекой Кура народах и землях и об их состоянии в 1728 году // История, география и этнография Дагестана XVIII - XIX вв. Архивные материалы. М., 1958. С. 60-118.

19. Гильденштедт И.А. Путешествие по Кавказу в 1770-1773 гг. СПб., 2002.

20. Григорьев В.В. Россия и Азия. СПб., 1876.

21. Григорьев А.П. Золотоордынские ярлыки: поиск и интерпретация // Тюркологический сборник 2005. М., 2006. С. 74-142.

22. Григорян В. История армянских колоний Украины и Польши (армяне в Подолии). Ереван, 1980.

23. Дашкевич Я. Камяниць-Подільский у вірменських джерелах XIV-XV ст. // Камянець-Подільский у контексті украінсько-европейських звязків: історія I сучасність. Камянець-Подільский, 2004.

24. Джамал ал-Карии. Ал-мулхакат би-с-сурах. Алматы, 2005.

25. Джованни Виллани. Новая хроника, или история Флоренции. М., 1997.

26. Дьячков-Тарасов А.Н. Заметки о Карачае и карачаевцах. Нальчик, 2009.

27. Жан де Жуанвиль, Жоффруа де Вилардуэн. История крестовых походов. М., 2008.

28. Зайцев И.В. Между Москвой и Стамбулом. М., 2004.

29. Зайцев И.В. Астраханское ханство. М., 2006.

30. Золотая Орда в источниках. М., 2003. Т. 1.

31. Иоанн Галонифонтибус. Сведения о народах Кавказа (1404 г.). Баку, 1979.

32. Історія Львова в документах і матеріалах. Киів, 1986.

33. Исхаков Д.М. Тюрко-татарские государства XV-XVI вв. Казань, 2009.

34. Караулов Н.А. Болкары на Кавказе. Нальчик, 2009.

35. Kлапрот Г.Ю. Описание поездок по Кавказу и Грузии в 1807 и 1808 годах. Нальчик, 2008.

36. Коковцов П.К. Еврейско-хазарская переписка в Х веке. Л., 1932.

37. Коновалова И.Г. Ал-Идриси о странах и народах Восточной Европы. М., 2006.

38. Костюков В.П. Была ли Золотая Орда «Кипчакским ханством»? // Тюркологический сборник 2005. М., 2006. С. 199-237.

39. Кабардино-русские отношения в XVI-XVIII веках. Нальчик, 2006. T. 1.

40. Кругосветное странствие раби Петахии Регенсбургского // Три еврейских путешественника. М., 2004. С. 259-318.

41. Куртиев Р. Календарные обряды крымских татар. Симферополь, 1996.

42. Лавров Л.И. Избранные труды по культуре абазин, адыгов, карачаевцев, балкарцев. Нальчик, 2009.

43. Ланге Б.А. Балкария и балкарцы. Нальчик, 2009.

44. Макаров Т. Татарское племя на Кавказе. Нальчик, 2009.

45. Марков Е.Л. Очерки Крыма. Киев, 2006.

46. Матвей Меховский. Трактат о двух Сарматиях. Рязань, 2009.

47. Махмуд ал-Камгари. Диван Лугат ат-Турк. Алматы, 2005.

48. Миллер В.Ф. Фольклор народов Северного Кавказа. М., 2008.

49. Михалон Литвин. О нравах татар, литовцев и москвитян. М., 1994.

50. Молчановский Н. Очерк известий о Подольской земле до 1434 года. Киев, 1885.

51. Нарышкин Н.А. Отчёт об экспедиции в Балкарию и Кабарду // Балкария: Страницы прошлого. Нальчик, 2005, вып. 1. С. 3-25.

52. Насилов Д.М. Кыпчаки у Махмуда Кашгарского // Тюркологический сборник 2007-2008. М., 2009. C. 284-293. 
53. Научное известие (Грамматические и филологические исследования Хюркилинского языка, П.К. Услара) // Кавказские горцы. Сборник сведений. М., 1992, т. 2. C. $79-85$.

54. Освобождение зависимых сословий во всех горских округах Терской области // Кавказские горцы. Сборник сведений. Т. 1. М., 1992. С. 37-47.

55. Полное собрание русских летописей. Лаврентьевская летопись. М., 1997. Т. 1.

56. Полное собрание русских летописей. Ипатьевская летопись. М., 2001. Т. 2.

57. Путешествие Ивана Шильтбергера по Европе, Азии и Африке, с 1394 года по 1427 год // Записки императорского Новороссийского университета. Новороссийск, 1867. Т. 1. C. $1-127$.

58. Путешествия в восточные страны. М., 1997.

59. Радлов В.В. Образцы народной литературы северных тюркских племён. Наречия Крымского полуострова. СПб., 1896, ч. VII.

60. Рахимзянов Б.Р. Касимовское ханство (1445-1552 гг.). Казань, 2009.

61. Робер де Клари. Завоевание Константинополя. М., 1986.

62. Роджер Бэкон. Великое сочинение // Английские средневековые источники IX-XIII вв. М., 1979.

63. Родословная туркмен. Сочинение Абу-л-гази, хана хивинского. М., 1958. 2007.

64. Россия и Европа глазами Орудж-бека Баята - Дон Жуана Персидского. СПб.,

65. Русско-чеченские отношения. Вторая половина XVI-XVII в. М., 1997.

66. Самойлович А.Н. Тюркское языкознание. Филология. Руника. М., 2005.

67. Сіцінський Ю. Поділля під владою Литви. Кам'янець-Подільський, 2009.

68. Смирнов В.Д. Крымское ханство под верховенством Оттоманской порты. М., 2005. T. 1.

69. Сравнительно-историческая грамматика тюркских языков. Региональные реконструкции. М., 2002.

70. Сравнительно-историческая грамматика тюркских языков. Картина мира пратюркского этноса по данным языка. М., 2006.

71. Сравнительно-историческая грамматика тюркских языков. М., 2010.

72. Сысоев B.M. Карачай в географическом, бытовом и историческом отношениях. Нальчик, 2009.

73. Султанов Т.И. Чингиз-хан и чингизиды. Судьба и власть. М., 2006.

74. Татарские князья и их княжества. Н. Новгород, 2008.

75. Тенишев Э.Р. К изучению тюркских языков Крыма // Известия АН СССР. Серия литературы и языка. М., 1995. Т. 54, № 1. С. 41-48.

76. Трепавлов В.В. Малая Ногайская Орда. Очерк истории // Тюркологический сборник 2003-2004. М., 2005. С. 273-311.

77. Трепавлов B.B. Власть и управление в тюркском кочевом обществе (по эпическим сказаниям народов Южной Сибири) // Тюркологический сборник 2005. М., 2006. С. 323-354.

78. Тунманн И. Крымское ханство. Симферополь, 1991.

79. Тюркские народы Крыма. М., 2003.

80. Фазлаллах ибн Рузбихан Исфахани. Михман-наме-йи Бухара (Записки бухарского гостя). М., 1976.

81. Фасмер М.Р. Этимологический словарь русского языка. М., 1986. Т. 1.

82. Шамхалы Тарковские // Кавказские горцы. Сборник сведений. М., 1992. Т. 1. C. $53-80$

83. Шумкин А.В. Маджары в фольклоре народов Северного Кавказа и письменных источниках // История народов России в исследованиях и документах. М., 2010. Вып. 4. С. 5-53.

84. Эвлия Челеби. Книга путешествия. М., 1979. Вып. 2.

85. Beresin I. Recherches sur les dialectes musulmans. Casan, 1848. 
86. Codex Antonio de Finale // Biblioteca Divi Marci - Biblioteca Nazionale di S. Marco - Biblioteca ad templum Divi Marci Venetiarum, Venezia, Mss. latini, Fondo antico, Collocazione 1597, Codex DXLIX / № 549.

87. Klaproth J. Notice sur un Dictionnaire Persan, Coman et Latin, légué par Pétrarque à la république de Venise // Journal asiatique. Paris, 1826, t. 8. P. 114-117.

88. Klaproth $J$. Vocabulaire latin, persan et coman, de la bibliothèque de Francesco Petrarcha // Mémoires relatifs à l'Asie. Paris, 1828, t. 3. P. 113-256.

89. Kuun G. Codex Cumanicus bibliotecae ad templum Divi Marci Venetarum. Budapest, 1880 .

90. Radloff $W$. Vergleichende Grammatik der nördlichen Türksprachen. Leipzig, 1882.

91. Radloff $W$. Das türkische Sprachmaterial des Codex Comanicus. St. Pétersbourg, 1887.

92. Yule H. Cathay and the way thither. L., 1866, vol. I-II.

Сведения об авторе: Арсений Вячеславович Шумкин - Федеральное агентство научных организаций (119334, Ленинский проспект, 32а, Москва, Российская Федерация). E-mail: arsen1293@rambler.ru

Поступила 3.09. 2016 г.

Принята к публикации 5.11.2016 г.

\title{
THE TATAR AND KIPCHAK LANGUAGES IN THE FRAMEWORKS OF ONE LINGUAGEOGRAPHIC RECONSTRUCTION
}

\author{
A.V. Shumkin \\ Federal Agency of Research Organizations \\ Moscow 119334, Russian Federation \\ E-mail: arsen1293@rambler.ru
}

Objective: To examine the origin and development of several Turkic languages spoken in the North Caucasus.

Research materials: the era of Turkic khanate domination in the steppes of Asia and Eastern Europe marked the formation of the ancient Turkic literary tradition. Initially it was displayed in the original Orkhon-Yenisey alphabet. Later, in the principality Kocho and Karakhanids' state this tradition was transliterated into alphabet borrowed from the Sogdians. In his work compiled in Arabic, Karakhanid Mahmoud al-Kashgari was first to describe Turkic-speaking dialects that differed from the ancient writing standards. Among them, he focused mainly on the languages of nomadic Oguz and Kipchak confederations. One after another they occupied the steppes of Eastern Europe and Central Asia. Based on al-Kashgari's information, the author of this article demonstrates that the territory occupied by the Kipchak confederation preserved Oghuz dialect used by Oghuz tribes Kangly and Karabërkli who joined to Kipchaks. The Kyrgyz branch of the Turkic languages brought by Kipchaks to the West spread in this area as well. The rise and conquest of the Great Mongol Empire changed the language boundaries and literary canons of Central Asia, Siberia and Eastern Europe forever. In the time of the Mongol Empire practice of bilingualism established in the area. Literary canons from now and until the first third of the $20^{\text {th }}$ century were based on the Turkic speech of Chagataid ulus of the Mongol Empire. On the other hand, examining the Antonio de Finale's manuscript composed at the beginning of the $14^{\text {th }}$ centu- 
ry on the territory of the Jochid Ulus, and a number of documents of the $16^{\text {th }}-18^{\text {th }}$ centuries written in the Lithuanian Tatar, the author reveals the formation history of Tatar branch of Turkic languages in the steppes of Dasht-i Kipchak.

Results and novelty of the research: on the basis of this information the article manages to conclude that both Chagatai and the Golden Horde languages were brought to the west during the Mongol invasions. Through the prism of these events, the article examines the problem of the origin and development of several Turkic languages spoken in the North Caucasus.

Keywords: North Caucasus, Turkic languages, historical linguistics, Tatar language, Kipchak language, Oghuz language.

For citation: Shumkin A.V. The Tatar and Kipchak Languages in the Frameworks of One Linguageographic Reconstruction. Golden Horde Review. 2016. Vol. 4, no. 4, pp. 698-723. DOI: 10.22378/2313-6197.2016-4-4.698-723

\section{REFERENCES}

1. Abdumanapov R.A. Kul'turno-istoricheskaya osnova kyrgyzskogo plemennogo obrazovaniya kangdy [The cultural and historical basis of Kyrgyz tribal formation Kangdy]. Tyurkologicheskiy sbornik [Turcologica]. Moscow, 2006, pp. 6-20. (In Russian)

2. Abramovich A. Ocherk soslovnogo stroya v gorskikh obshchestvakh Terskoy i Kubanskoy oblastey [Essay of the estate sructure among the mountain communities of the Kuban and Terek regions]. Sbornik dokumentov po soslovnomu pravu narodov Severnogo Kavkaza [Collection of documents on the estate rights of the peoples of the North Caucasus]. Nal'chik, 2003, vol. 1, pp. 19-72. (In Russian)

3. 'Adzhai'ib ad-dunya (chudesa mira) [The wonders of the world]. Moscow, 1993. (In Russian)

4. Anna Komnena. Alexiad. St. Petersburg, 1996. (In Russian)

5. Anuchin D.N. Rossiya v etnograficheskom otnoshenii [Russia from the standpoint of etnography]. Entsiklopedicheskiy slovar' Rossiya [Encyclopedic Dictionary of Russia]. St. Petersburg, 1991, pp. 139-152. (In Russian)

6. Aristov N.A. Zametki ob etnicheskom sostave tyurkskikh plemen i narodnostey [Notes about ethnic structure of Turkic tribes and nations]. Zhivaya starina [Living Antiquity]. St. Petersburg, 1896, is. III-IV, pp. 277-456. (In Russian)

7. Bakikhanov Abbas-Kuli-aga. Gyulistan-i Iram. Baku, 1991. (In Russian)

8. Bartol'd V.V. Raboty po istoricheskoy geografii [Works on the historical geography]. Moscow, 2002. (In Russian)

9. Bartol'd V.V. Raboty po istorii i filologii tyurkskikh i mongol'skikh narodov [Works on the history and philology of Turkic and Mongolian nations]. Moscow, 2002. (In Russian) sian)

10. Baskakov N.A. Tyurkskie yazyki [The Turkic languages]. Moscow, 2006. (In Rus-

11. Bespalov R.A. Khan Ulu-Mukhammed i gosudarstva Vostochnoy Evropy: ot Beleva do Kazani (1437-1445) [Khan Ulu-Muhammed and the states of Eastern Europe: from Belev to Kazan (1437-1445)]. Zolotoordynskaya tsivilizatsiya [Golden Horde Civilization]. Kazan, 2012, is. 5, pp. 53-70. (In Russian)

12. Blaramberg I.F. Istoricheskoe, topograficheskoe, statisticheskoe, etnograficheskoe, $i$ voennoe opisanie Kavkaza [The historical, topographical, statistical, ethnographical and military description of the Caucasus]. Moscow, 2010. (In Russian)

13. Bronevskiy S.M. Noveyshiya Izvestiya o Kavkaze, sobrannyya $i$ popolnennyya Semenom Bronevskim [The latest information about the Caucasus, collected and supplemented by Semen Bronevsky]. St. Petersburg, 2004. (In Russian) 
14. Garkavets A.N. Kypchakskoe pis'mennoe nasledie [Kypchak written heritage]. Katalog i teksty armyanskim pis'mom. Almaty, 2002, vol. 1. (In Russian)

15. Garkavi A.Y. Po voprosu o iudeyskikh drevnostyakh, naydennykh Firkovichem v Krymu [On the issue of Jewish antiquities found by Firkowicz in the Crimea]. Zhurnal Ministerstva narodnogo prosveshcheniya [Journal of Ministry of Public Education]. St. Petersburg 1877, part. CXCII, pp. 98-121. (In Russian)

16. Garkavi A.Y. Karaimy [Karaites]. Brockhaus F.A., Efron I.A. Entsiklopedicheskiy slovar' [Encyclopedic Dictionary]. St. Petersburg, 1895, vol. 14, pp. 426-432. (In Russian)

17. Georgi I.G. Opisanie vsekh obitayushchikh v Rossiyskom gosudarstve narodov [A description of all nations living in the Russian State]. St. Petersburg, 2007. (In Russian)

18. Gerber I.G. Zapiski o nakhodyashchikhsya na zapadnom beregu Kaspiyskogo morya, mezhdu Astrakhan'yu i rekoy Kura narodakh i zemlyakh i ob ikh sostoyanii v 1728 godu [Notes on nations and lands located on the western shore of the Caspian Sea between Astrakhan and the river Kura and their state in 1728]. Istoriya, geografiya i etnografiya Dagestana XVIII-XIX vv. Arkhivnye materialy [History, geography and ethnography of Dagestan in the $18^{\text {th }}-19^{\text {th }}$ centuries. Archival materials]. Moscow, 1958, pp. 60-118. (In Russian)

19. Gil'denshtedt I.A. Puteshestvie po Kavkazu v 1770-1773 gg [A Journey to the Caucasus in 1770-1773]. St. Petersburg, 2002. (In Russian) sian)

20. Grigor'ev V.V. Rossiya i Aziya [Russia and Asia]. St. Petersburg, 1876. (In Rus-

21. Grigor'ev A.P. Zolotoordynskie yarlyki: poisk i interpretatsiya [Golden Horde yarliqs: search and interpretation]. Tyurkologicheskiy sbornik 2005 [Turcologica 2005]. Moscow, 2006, pp. 74-142. (In Russian)

22. Grigoryan V. Istoriya armyanskikh koloniy Ukrainy i Pol'shi (armyane v Podolii) [History of Armenian colonies in Ukraine and Poland (Armenians in Podolia)]. Erevan, 1980. (In Russian)

23. Dashkevich Ya. Kamyanits'-Podil'skiy u virmens'kikh dzherelakh XIV-XV st. [Kamyanitsa-Podilsky in Armenian documents of the $14^{\text {th }}-15^{\text {th }}$ centuries] Kamyanets'Podil'skiy u konteksti ukrains'ko-evropeys'kikh zvyazkiv: istoriya i suchasnist' [Kamyanitsa-Podilsky in the context of Ukrainian-European relations: History and Present]. Kamyanets'-Podil'skiy, 2004. (In Ukranian)

24. Jamal al-Karshi. Al-mulkhakat bi-s-surakh. Almaty, 2005. (In Russian)

25. Giovanni Villani. Novaya khronika, ili istoriya Florentsii [New Chronicle, or a history of Florence]. Moscow, 1997. (In Russian)

26. D'yachkov-Tarasov A.N. Zametki o Karachae $i$ karachaevtsakh [Notes on the Karachai and Karachais]. Nal'chik, 2009.

27. Jean de Joinville, Geoffroi de Villehardouin. Istoriya krestovykh pokhodov [History of the Crusades]. Moscow, 2008. (In Russian)

28. Zaytsev I.V. Mezhdu Moskvoy i Stambulom [Between Moscow and Istanbul]. Moscow, 2004. (In Russian) Russian)

29. Zaytsev I.V. Astrakhanskoe khanstvo [Astrakhan Khanate]. Moscow, 2006. (In

30. Zolotaya Orda v istochnikakh [Golden Horde in the sources]. Moscow, 2003, vol. 1. (In Russian)

31 Johannes de Galonifontibus. Svedeniya o narodakh Kavkaza (1404 g.) [Information about the nations of the Caucasus (1404)]. Baku, 1979. (In Russian)

32. Istoriya L'vova $v$ dokumentakh $i$ materialakh [The history of Lvov in documents and materials]. Kyiv, 1986. (In Ukranian)

33. Iskhakov D.M. Tyurko-tatarskie gosudarstva XV-XVI vv. [Turkic-Tatar states in the $15^{\text {th }}-16^{\text {th }}$ centuries]. Kazan, 2009. (In Russian)

34. Karaulov N.A. Bolkary na Kavkaze [Bolkars in the Caucasus]. Nal'chik, 2009. (In Russian) 
35. Klaprot G.Y. Opisanie poezdok po Kavkazu i Gruzii v 1807 i 1808 godakh [The description of trips in the Caucasus and Georgia in 1807 and 1808]. Nal'chik, 2008. (In Russian)

36. Kokovtsov P.K. Evreysko-khazarskaya perepiska v X veke [Jewish-Khazar correspondence in the $10^{\text {th }}$ century]. Leningrad, 1932. (In Russian)

37. Konovalova I.G. Al-Idrisi o stranakh i narodakh Vostochnoy Evropy [Al-Idrisi about the countries and nations of Eastern Europe]. Moscow, 2006. (In Russian)

38. Kostyukov V.P. Byla li Zolotaya Orda «Kipchakskim khanstvom»? [Wether the Golden Horde was the "Kipchak Khanate"?]. Tyurkologicheskiy sbornik 2005 [Turcologica 2005]. Moscow, 2006, pp. 199-237. (In Russian)

39. Kabardino-russkie otnosheniya v XVI-XVIII vekakh [Kabardian-Russian relations in the $16^{\text {th }}-18^{\text {th }}$ centuries]. Nal'chik, 2006, vol. 1. (In Russian)

40. Krugosvetnoe stranstvie rabi Petakhii Regensburgskogo [Voyage around the world of Rabbi Pethahiah of Regensburg]. Tri evreyskikh puteshestvennika [Three Jewish travelers]. Moscow, 2004, pp. 259-318. (In Russian)

41. Kurtiev R. Kalendarnye obryady krymskikh tatar [Calendar rites of the Crimean Tatars]. Simferopol, 1996. (In Russian)

42. Lavrov L.I. Izbrannye trudy po kul'ture abazin, adygov, karachaevtsev, balkartsev [Selected works on culture of Abaza, Circassians, Karachais, Balkars]. Nal'chik, 2009. (In Russian)

43. Lange B.A. Balkariya i balkartsy [Balkaria and Balkars]. Nal'chik, 2009. (In Russian)

44. Makarov T. Tatarskoe plemya na Kavkaze [Tatar tribes in the Caucasus]. Nal'chik, 2009. (In Russian)

45. Markov E.L. Ocherki Kryma [Sketches of the Crimea]. Kyiv, 2006. (In Russian)

46. Matthaeus Mechovita. Traktat o dvukh Sarmatiyakh [Treatise on the two Sarmatia]. Ryazan, 2009. (In Russian)

47. Mahmud al-Kashgari. Divan Lugat at-Turk. Almaty, 2005. (In Russian)

48. Miller V.F. Fol'klor narodov Severnogo Kavkaza [The folklore of the nations of the North Caucasus]. Moscow, 2008. (In Russian)

49. Michalon Lituanus. O nravakh tatar, litovtsev i moskvityan [About the mores of Tatars, Lithuanians and Muscovites.]. Moscow, 1994. (In Russian)

50. Molchanovskiy N. Ocherk izvestiy o Podol'skoy zemle do 1434 goda [Essay on information of Podolsk land until 1434]. Kyiv, 1885. (In Russian)

51. Naryshkin N.A. Otchet ob ekspeditsii v Balkariyu i Kabardu [The report on the expedition in Balkaria and Kabarda]. Balkariya: Stranitsy proshlogo [Balkaria: Pages of the past]. Nal'chik, 2005, is. 1, pp. 3-25. (In Russian)

52. Nasilov D.M. Kypchaki u Makhmuda Kashgarskogo [Kypchaks according to Mahmoud of Kashgar]. Tyurkologicheskiy sbornik 2007-2008 [Turcologica 2007-2008]. Moscow, 2009, pp. 284-293. (In Russian)

53. Nauchnoe izvestie (Grammaticheskie i filologicheskie issledovaniya Khyurkilinskogo yazyka, P.K. Uslara) [Academic proceedings (grammatical and philological researches of Hyurkili language, P.K. Uslar)]. Kavkazskie gortsy. Sbornik svedeniy [Caucasian mountaineers. Collection of information]. Moscow, 1992, vol. 2, pp. 79-85. (In Russian)

54. Osvobozhdenie zavisimykh sosloviy vo vsekh gorskikh okrugakh Terskoy oblasti [Exemption of dependent classes in the mountain districts of the Terek region]. Kavkazskie gortsy. Sbornik svedeniy [Caucasian mountaineers. Collection of information]. Moscow, 1992, vol. 1, pp. 37-47. (In Russian)

55. Polnoe sobranie russkikh letopisey [Complete Collection of Russian Chronicles]. Lavrent'evskaya leto-pis' [Laurentian Chronicle]. Moscow, 1997, vol. 1. (In Russian)

56. Polnoe sobranie russkikh letopisey [Complete Collection of Russian Chronicles]. Ipat'evskaya letopis' [Hypathian Chronicle]. Moscow, 2001, vol. 2. (In Russian) 
57. Puteshestvie Ivana Shil'tbergera po Evrope, Azii i Afrike, s 1394 goda po 1427 god [Johannes Schiltberger's Travel to Europe, Asia and Africa, from 1394 till 1427]. Zapiski imperatorskogo Novorossiyskogo universiteta [Notes of Imperial Novorossiysk University]. Novorossiysk, 1867, vol. 1, pp. 1-127. (In Russian)

58. Puteshestviya $v$ vostochnye strany [Travels to the Eastern countries]. Moscow, 1997. (In Russian)

59. Radlov V.V. Obraztsy narodnoy literatury severnykh tyurkskikh plemen [Samples of folk literature of Turkic tribes of the north]. Narechiya Krymskogo poluostrova [Dialects of the Crimean peninsula]. St. Petersburg, 1896, part. VII. (In Russian)

60. Rakhimzyanov B. Kasimovskoe khanstvo (1445-1552 gg.) [Kasimov Khanate (1445-1552)]. Kazan, 2009. (In Russian)

61. Robert de Clari. Zavoevanie Konstantinopolya [The conquest of Constantinople]. Moscow, 1986. (In Russian)

62. Roger Bacon. Velikoe sochinenie [Opus maius]. Angliyskie srednevekovye istochniki IX-XIII vv. [English medieval sources of the $9^{\text {th }}-13^{\text {th }}$ centuries]. Moscow, 1979. (In Russian)

63. Rodoslovnaya Turkmen [Genealogy of the Turkmen]. Sochinenie Abu-l-gazi, khana khivinskogo [The work of Abu-l-Ghazi, khan of Khiva]. Moscow, 1958. (In Russian)

64. Rossiya i Evropa glazami Orudzh-beka Bayata - Don Zhuana Persidskogo [Russia and Europe through the eyes Oruj Bek Bayat - Don Juan of Persia]. St. Petersburg, 2007. (In Russian)

65. Russko-chechenskie otnosheniya [Russian-Chechen relations]. Vtoraya polovina XVI-XVII v. [Second half of the $16^{\text {th }}-17^{\text {th }}$ centuries]. Moscow, 1997. (In Russian)

66. Samoylovich A.N. Tyurkskoe yazykoznanie [Turkic linguistics]. Filologiya. Runika [Philology. Runes]. Moscow, 2005. (In Russian)

67. Sitsins'kiy Y. Podillya pid vladoyu Litvi [Podillya under the rule of Lithuania]. Kam'yanets'-Podil's'kiy, 2009. (In Ukranian)

68. Smirnov V.D. Krymskoe khanstvo pod verkhovenstvom Ottomanskoy porty [Crimean Khanate under the rule of Ottoman Port]. Moscow, 2005, vol. 1. (In Russian)

69. Sravnitel'no-istoricheskaya grammatika tyurkskikh yazykov [A comparative historical grammar of Turkic languages]. Regional'nye rekonstruktsii [Regional reconstruction]. Moscow, 2002. (In Russian)

70. Sravnitel'no-istoricheskaya grammatika tyurkskikh yazykov [A comparative historical grammar of Turkic languages]. Kartina mira pratyurkskogo etnosa po dannym yazyka [Picture of the world of the proto-Turkic ethnic group according to the language information]. Moscow, 2006. (In Russian)

71. Sravnitel'no-istoricheskaya grammatika tyurkskikh yazykov [A comparative historical grammar of Turkic languages]. Moscow, 2010. (In Russian)

72. Sysoev V.M. Karachay $v$ geograficheskom, bytovom $i$ istoricheskom otnosheniyakh [Karachai in geographical, historical and domestic relations]. Nal'chik, 2009. (In Russian)

73. Sultanov T.I. Chingiz-khan $i$ chingizidy [Chinggis Khan and the Chinggisids]. Sud'ba i vlast' [Destiny and power]. Moscow, 2006. (In Russian)

74. Tatarskie knyaz'ya i ikh knyazhestva [Tartar princes and their principalities]. Nizhniy Novgorod, 2008. (In Russian)

75. Tenishev E.R. K izucheniyu tyurkskikh yazykov Kryma [To the study of the Turkic languages of the Crimea]. Izvestiya Akademii nauk SSSR. Seriya literatury $i$ yazyka [Proceedings of the Academy of Sciences of the USSR. Series of Literature and Language]. Moscow, 1995, vol. 54, no. 1, pp. 41-48. (In Russian)

76. Trepavlov V.V. Malaya Nogayskaya Orda [Minor Nogai Horde]. Tyurkologicheskiy sbornik 2003-2004 [Turcologica 2003-2004]. Moscow, 2005, pp. 273-311. (In Russian) 
77. Trepavlov V.V. Vlast' i upravlenie v tyurkskom kochevom obshchestve (po epicheskim skazaniyam narodov Yuzhnoy Sibiri) [Power and administration in the Turkic nomadic societies (based on epic tales of the peoples of South Siberia)]. Tyurkologicheskiy sbornik 2005 [Turcologica 2005]. Moscow, 2006, pp. 323-354. (In Russian)

78. Tunmann I. Krymskoe khanstvo [Crimean Khanate]. Simferopol, 1991. (In Russian)

79. Tyurkskie narody Kryma [The Turkic nations of Crimea]. Moscow, 2003. (In Russian)

80. Fadl Allak ibn Rudhbi Khan al-Isfahani. Mikhman-name-yi Bukhara (Zapiski bukharskogo gostya) [Bukhara guest notes]. Moscow, 1976. (In Russian)

81. Fasmer M.R. Etimologicheskiy slovar' russkogo yazyka [Etymological dictionary of the Russian language]. Moscow, 1986, vol. 1. (In Russian)

82. Shamkhaly Tarkovskie [The shamkhals of Tarki]. Kavkazskie gortsy. Sbornik svedeniy [Caucasian mountaineers. Collection of information]. Moscow, 1992, vol. 1, pp. 53-80. (In Russian)

83. Shumkin A.V. Madzhary v fol'klore narodov Severnogo Kavkaza i pis'mennykh istochnikakh [The Majars in the folklore of the nations of the North Caucasus and written sources]. Istoriya narodov Rossii $v$ issledovaniyakh $i$ dokumentakh [History of the peoples of Russia in the studies and documents]. Moscow, 2010, is. 4, pp. 5-53. (In Russian)

84. Evliya Çelebi. Kniga puteshestviya [The book of travel]. Moscow, 1979, is. 2. (In Russian)

85. Beresin I. Recherches sur les dialectes musulmans. Casan, 1848. (In French)

86. Codex Antonio de Finale. Biblioteca Divi Marci - Biblioteca Nazionale di S. Marco - Biblioteca ad templum Divi Marci Venetiarum, Venezia, Mss. latini, Fondo antico, Collocazione 1597, Codex DXLIX / № 549. (In Latin)

87. Klaproth J. Notice sur un Dictionnaire Persan, Coman et Latin, légué par Pétrarque à la république de Venise. Journal asiatique. Paris, 1826, vol. 8, pp. 114-117. (In French)

88. Klaproth J. Vocabulaire latin, persan et coman, de la biblioètheque de Francesco Petrarcha. Mémoires relatifs à l'Asie. Paris, 1828, vol. 3, pp. 113-256. (In French)

89. Kuun G. Codex Cumanicus bibliotecae ad templum Divi Marci Venetarum. Budapest, 1880. (In Latin)

90. Radloff W. Vergleichende Grammatik der nördlichen Türksprachen. Leipzig, 1882. (In German)

91. Radloff W. Das türkische Sprachmaterial des Codex Comanicus. St. Pétersbourg, 1887. (In German)

92. Yule H. Cathay and the way thither. Leningrad, 1866, vol. I-II. (In English)

About the author: Arseniy V. Shumkin - Federal Agency of Research Organizations (32a, Leninsky prospect, Moscow 119334, Russian Federation). E-mail: arsen1293@rambler.ru

Received September 3, 2016 Accepted for publication November 5, 2016 